University of Nebraska - Lincoln

DigitalCommons@University of Nebraska - Lincoln

Faculty Publications from the Harold W. Manter Laboratory of Parasitology

6-1997

\title{
Six Species of Acanthobothrium (Eucestoda: Tetraphyllidea) in Stingrays (Chondrichthyes: Rajiformes: Myliobatoidei) from Ecuador
}

\author{
Fernando Marques \\ University of Toronto \\ Daniel R. Brooks \\ University of Toronto,dnlbrooks@gmail.com \\ Ramiro Barriga \\ Escuela Politecnica Nacional (Quito, Ecuador)
}

Follow this and additional works at: https://digitalcommons.unl.edu/parasitologyfacpubs

Part of the Parasitology Commons

\begin{abstract}
Marques, Fernando; Brooks, Daniel R.; and Barriga, Ramiro, "Six Species of Acanthobothrium (Eucestoda: Tetraphyllidea) in Stingrays (Chondrichthyes: Rajiformes: Myliobatoidei) from Ecuador" (1997). Faculty Publications from the Harold W. Manter Laboratory of Parasitology. 228.

https://digitalcommons.unl.edu/parasitologyfacpubs/228
\end{abstract}

This Article is brought to you for free and open access by the Parasitology, Harold W. Manter Laboratory of at DigitalCommons@University of Nebraska - Lincoln. It has been accepted for inclusion in Faculty Publications from the Harold W. Manter Laboratory of Parasitology by an authorized administrator of DigitalCommons@University of Nebraska - Lincoln. 


\title{
SIX SPECIES OF ACANTHOBOTHRIUM (EUCESTODA: TETRAPHYLLIDEA) IN STINGRAYS (CHONDRICHTHYES: RAJIFORMES: MYLIOBATOIDEI) FROM ECUADOR
}

\author{
Fernando Marques, Daniel R. Brooks, and Ramiro Barriga* \\ Center for Historical Ecology and Biodiversity, Department of Zoology, University of Toronto, Toronto, Ontario, Canada M5S $3 G 5$
}

\begin{abstract}
Six species of Acanthobothrium, 4 described as new, are reported in stingrays from southern Ecuador. Acanthobothrium atahualpai $\mathrm{n}$. sp. in Gymnura afuerae most closely resembles Acanthobothrium fogeli and Acanthobothrium parviuncinatum by having bothridial hooks with recurved prongs and short handles. It differs from A. fogeli by having bothridial hooks 163-195 $\mu \mathrm{m}$ vs. $78-114 \mu \mathrm{m}$ long and averaging 25 vs. 32 testes per proglottis; it differs from A. parviuncinatum by having bothridial hooks $163-195 \mu \mathrm{m}$ vs. $87 \mu \mathrm{m}$ long and averaging 25 vs. 13 testes per proglottis. Acanthobothrium minusculus $\mathrm{n}$. $\mathrm{sp}$. in Urolophus tumbesensis most resembles Acanthobothrium campbelli and Acanthobothrium vargasi by being no more than $3 \mathrm{~mm}$ long and having 6-30 testes per proglottis. It can be distinguished from them by having bothridial hooks averaging $86 \mu \mathrm{m}$ vs. 108-111 $\mu \mathrm{m}$ and $130-133 \mu \mathrm{m}$ long, and 6-10 vs. 15-23 and 22-29 testes per proglottis, respectively. Acanthobothrium monksi $\mathrm{n}$. sp. in Aetobatus narinari resembles Acanthobothrium tasajerasi from Himantura schmardae by having a prominent genital atrium and a large globose cirrus sac; it differs by averaging 21 vs. 35 testes per proglottis and having bothridial hooks averaging $150 \mu \mathrm{m}$ vs. $165 \mu \mathrm{m}$ long. Acanthobothrium obuncus $\mathrm{n}$. sp. in Dasyatis longus resembles a group of species characterized by wider than long to square immature and mature proglottides, bothridia at least partially fused to the scolex at their posterior ends, and asymmetrical ovarian arms with aporal arms extending anteriorly to the vaginal level. It resembles Acanthobothrium americanum by averaging 73 vs. 72 testes per proglottis, but differs by having bothridial hooks averaging $120-131 \mu \mathrm{m}$ vs. $151 \mu \mathrm{m}$ long; it resembles Acanthobothrium chilensis by having bothridial hooks averaging $120-131 \mu \mathrm{m}$ vs. $130 \mu \mathrm{m}$ long, but differs by averaging 73 vs. 90 testes per proglottis. Acanthobothrium campbelli in Urotrygon chilensis and Acanthobothrium costarricense in Dasyatis longus, previously known in those hosts from the Pacific coast of Costa Rica, are reported from Ecuador for the first time.
\end{abstract}

The tetraphyllidean cestode genus Acanthobothrium van Beneden 1849 , represented by over 100 nominal species, is the most species-rich genus within the Onchobothriidae. Recent descriptions of new species of cestodes from the Eastern Pacific have discussed morphological similarities between them and species in the Caribbean (Marques et al., 1995, 1996), suggesting that they might constitute pairs of sister species that diverged from their common ancestors as a result of the formation of the Isthmus of Panama or some other significant geographic isolation event. These assertions have been based either on unique morphological features (Marques et al., 1996) or on hypotheses that their hosts are sister species, e.g., Himatura pacifica (Beebe \& Tee-Van) and Himatura schmardae (Werner) (Lovejoy, 1996). At present, there is no robust phylogenetic analysis of Acanthobothrium to serve as a test for these postulates. Nevertheless, we consider them explicit predictions that can be submitted to direct test once such a phylogenetic hypothesis is produced. In this paper, we describe 4 new species of Acanthobothrium inhabiting stingrays from Ecuador and compare them with other morphologically similar species within the genus with an emphasis on their biogeographical distributions.

\section{MATERIALS AND METHODS}

During November of 1993, 2 Gymnura afuerae Hildebrand, 5 Urolophus tumbesensis Chirichigno and McEachran, 1 Aetobatus narinari (Euphrasen), and 5 Dasyatis longus Garman were captured in various localities in El Oro Province, Ecuador, using gill nets. Worms were removed from the host intestine, killed with hot tap water, transferred immediately to AFA for $24-48 \mathrm{hr}$, and then stored in $70 \%$ ethanol. Specimens were stained with Mayer's hematoxylin and mounted in Canada balsam for examination as whole mounts. Measurements are in $\mu \mathrm{m}$

Received 5 January 1996; revised 17 July 1996; accepted 17 July 1996.

* Departamento de las Ciencias Biológicas, Escuela Politecnica Nacional, Apartado 2759, Quito, Ecuador. unless otherwise stated; for some traits, ranges are given, followed in parentheses by mean values \pm 1 standard deviation and the sample size (n), except for samples of 2 for which only the range is provided. Hook measurements follow Marques et al. (1995). Figures were drawn with the aid of a drawing tube. The tetralobed nature of the ovaries was confirmed from lateral views of unmounted specimens and from whole mounts because sufficient material for sectioning was not available. CHIOC refers to the Coleção Helmintológica do Instituto Oswaldo Cruz, Rio de Janeiro, Brazil; MEPN refers to the Museum of the Escuela Politécnica Nacional, Quito, Ecuador; MNHG refers to the Museum of Natural History, Geneva, Switzerland; HWML refers to the University of Nebraska State Museum, Harold W. Manter Laboratory, Division of Parasitology, Lincoln, Nebraska, USA; and USNPC refers to United States National Parasite Collection, Beltsville, Maryland, USA. Comparisons were based on the latest publication for a given species unless an accession number is specified.

\section{DESCRIPTIONS}

Acanthobothrium atahualpai n. sp.

(Fig. 1A-D)

Description (based on 2 complete and 1 incomplete specimens): Strobila acraspedote, apolytic, up to $2.1 \mathrm{~mm}$ long; composed of up to 17 proglottides. Scolex 316-426 wide, composed of 4 triloculate bothridia free at posterior end with velum between adjacent bothridia; each bothridium with apical sucker and pad, armed with pair of bifid hooks. Bothridia $422-435(429 \pm 5, \mathrm{n}=3)$ long by $150-205(173 \pm 23, \mathrm{n}=$ 4) wide; anterior loculi $272-310(295 \pm 17, \mathrm{n}=3)$ long, middle loculi $70-74(71 \pm 1, n=3)$ long, posterior loculi 51-80 $(62 \pm 13, \mathrm{n}=3)$ long. Ratio of locular lengths 1:0.23:0.20. Muscular pads 189-227 (211 $\pm 15, n=4)$ wide, with median indentation, bearing apical sucker 48 $(n=2)$ in diameter. Hook formula for lateral hooks $(n=2)$ :

$$
\frac{32-35 \quad 144-147 \quad 154-166}{193-195}
$$

Hook formula for medial hooks $(\mathrm{n}=2)$ :

$$
\frac{32 \quad 134-141 \quad 128-134}{163-166}
$$

Ratio of bothridial length to total hook length 1:0.41 for lateral hooks and 1:0.38 for medial hooks. Cephalic peduncle spined 358-563 (457 $\pm 84, \mathrm{n}=3)$ long, $106(\mathrm{n}=1)$ wide at insertion to scolex. Immature 

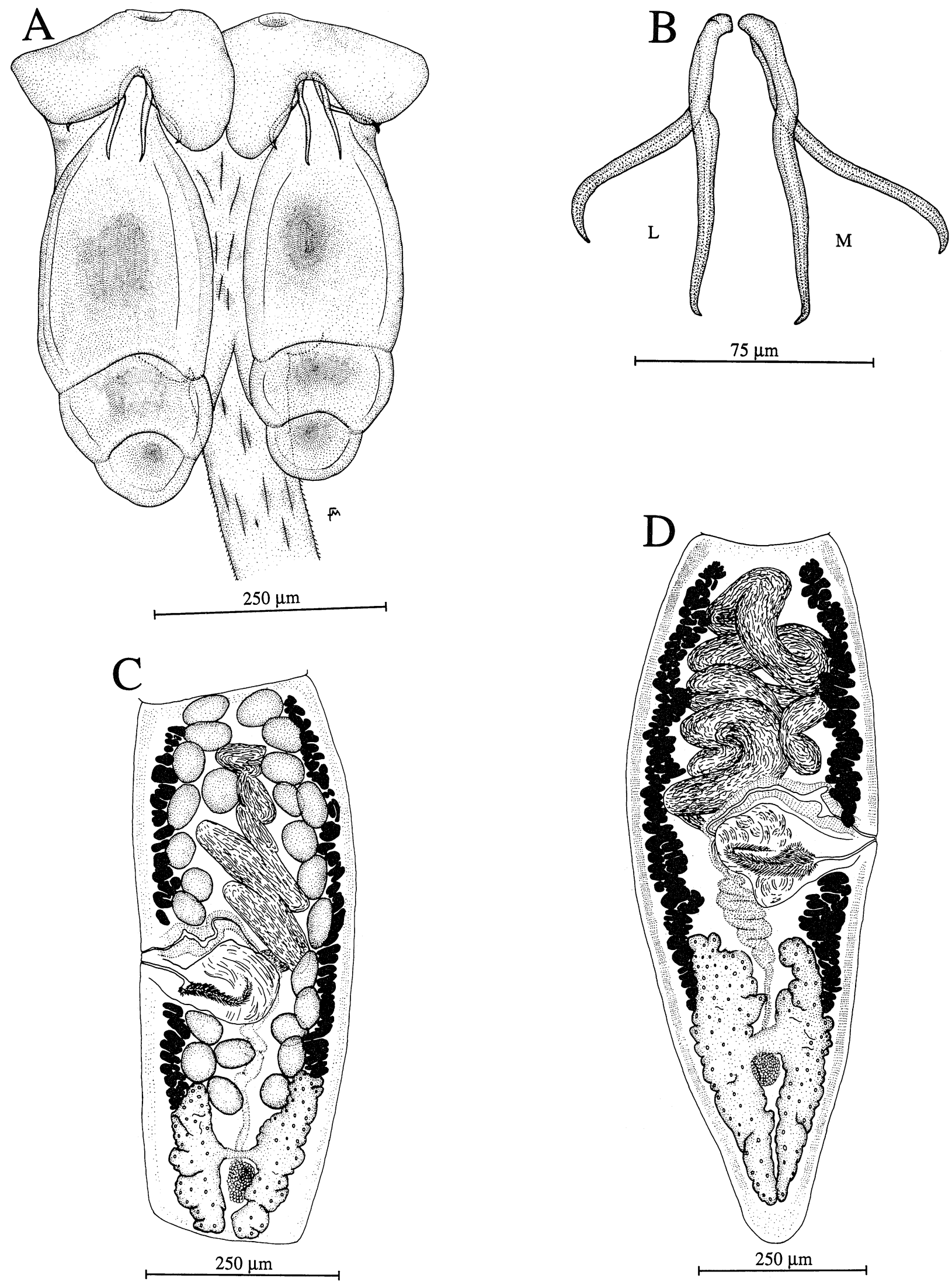

Figure 1. Acanthobothrium atahualpai n. sp. A. Scolex. B. Medial and lateral hooks. C. Mature proglottis. D. terminal proglottis. M = medial hook; $\mathrm{L}=$ lateral hook. 
proglottides wider than long. Mature terminal proglottides $918-1,168$ $(1,042 \pm 102, \mathrm{n}=3)$ long by $355-426$ wide. Testes 35-61 $(51 \pm 8, \mathrm{n}$ $=6)$ in diameter; $20-30(25 \pm 3, \mathrm{n}=5)$ in number, $4-10(7 \pm 2, \mathrm{n}$ = 5) preporally, 4-6 $(5 \pm 1, \mathrm{n}=5)$ postporally, $12-15(13 \pm 1, \mathrm{n}=$ 5 ) antiporally. Cirrus sac near midproglottis, $160-250$ long by $128-157$ wide, containing spined eversible cirrus. Genital atrium indistinct. Genital pore $42-47 \%$ of total length from anterior end, irregularly alternating. Vagina anterior to cirrus sac; vaginal sphincter not observed. Ovary near posterior end of proglottis, $\forall$-shaped in frontal view, $X$-shaped in cross section; 158-269 $(210 \pm 34, \mathrm{n}=7)$ wide at isthmus. Ovarian arms unequal in length, not reaching posterior margin of cirrus sac; aporal arm 371-592 long; poral arm 394-550 long. Uterus not observed. Vitelline follicles extending from level of ovarian isthmus to near anterior end of proglottis; follicles approximately oval, 29-51 (40 $\pm 7, \mathrm{n}=9$ ) wide.

\section{Taxonomic summary}

Host: Gymnura afuerae Hildebrand (Rajiformes: Myliobatidae).

Site of infection: Spiral valve.

Locality: Puerto Bolívar, Provincia de El Oro, Ecuador $\left(3^{\circ} 16^{\prime} \mathrm{S}\right.$ : $\left.80^{\circ} 19^{\prime} \mathrm{W}\right)$.

Holotype: MEPN no. 3029.

Paratypes: MNHG no. 22098.

Etymology: The species is named for the last Incan Emperor, Atahualpa.

\section{Remarks}

Acanthobothrium atahualpai, Acanthobothrium parviuncinatum Young, 1958 in Gymnura marmorata (Cooper) and Urolophus halleri (Cooper) from California, and Acanthobothrium fogeli Goldstein, 1964 in Gymnura micrura (Bloch and Schneider) from the Gulf of Mexico, are the only members of the genus possessing recurved tips of the bothridial hook prongs and short handles. Acanthobothrium atahualpai differs from these species by having longer hooks (up to $195 \mu \mathrm{m}$ ) and terminal proglottides (up to $1,042 \mu \mathrm{m}$ ) than A. fogeli $(98 \mu \mathrm{m}$ and 517 $\mu \mathrm{m}$, respectively) and $A$. parviuncinatum $(87 \mu \mathrm{m}$ and $640 \mu \mathrm{m}$, respectively). Acanthobothrium atahualpai differs from A. fogeli by having a strobila up to $2.1 \mathrm{~mm}$ rather than $4.8 \mathrm{~mm}$ long, by having up to 17 rather than up to 35 proglottides per strobila, bothridial apical suckers averaging $48 \mu \mathrm{m}$ rather than $80 \mu \mathrm{m}$ in diameter, an average of 25 rather than 46 testes per proglottis, and slightly longer cirrus sacs (up to 246 $\mu \mathrm{m}$ vs. up to $228 \mu \mathrm{m}$ ). Further, A. fogeli differs from A. atahualpai by lacking postovarian testes and having a genital pore posterolateral to the ovary rather than preovarian. Acanthobothrium atahualpai differs from $A$. parviuncinatum by having extremely slender rather than relatively robust bothridial hook prongs and longer hooks (averaging 146 $\mu \mathrm{m}$ (inner) and $160 \mu \mathrm{m}$ (outer) long vs. $70 \mu \mathrm{m}$ (inner) and $62 \mu \mathrm{m}$ (outer) long), and by having 20-35 rather than 12-14 testes per proglottis.

\section{Acanthobothrium minusculus n. sp.} (Fig. 2A-C)

Description (based on 20 specimens): Strobila acraspedote, apolytic, 1-2 mm (1.4 $\pm 0.3, n=18)$ long; composed of up to $11(7 \pm 2, n=$ 19) proglottides. Scolex 157-214 (187 $\pm 18, n=16)$ wide, composed of 4 triloculate bothridia free at posterior end; each bothridium with apical sucker and pad, armed with pair of bifid hooks. Bothridia 179$227(203 \pm 13, \mathrm{n}=34)$ long by $77-109(90 \pm 8, \mathrm{n}=35)$ wide; anterior loculi 115-147 (130 $\pm 9, n=34)$ long, middle loculi 26-42 (34 \pm 4 $\mathrm{n}=34)$ long, posterior loculi $32-48(39 \pm 4, \mathrm{n}=34)$ long. Ratio of locular lengths 1:0.27:0.30. Muscular pads 45-80 (60 $\pm 9, \mathrm{n}=29)$ wide, bearing apical sucker 29-37 $(33 \pm 2, \mathrm{n}=20)$ in diameter. Hook formula for lateral hooks $(n=26)$ :

$$
\frac{26 \pm 1(22-29) \quad 64 \pm 4(56-74) \quad 54 \pm 4(48-68)}{86 \pm 5(78-98)}
$$

Hook formula for medial hooks $(n=27)$ :

$$
\frac{25 \pm 2(22-29) \quad 63 \pm 4(58-72) \quad 54 \pm 3(51-61)}{86 \pm 4(78-96)}
$$

Ratio of bothridial length to total hook length 1:0.44 for lateral and medial hooks. Cephalic peduncle and scolex with spines. Peduncle 138$234(188 \pm 26, \mathrm{n}=20) \mathrm{mm}$ long, 48-77 $(61 \pm 9, \mathrm{n}=19)$ wide at insertion to scolex. Immature proglottides wider than long. Mature terminal proglottides $378-538(463 \pm 49, \mathrm{n}=9)$ long by $96-157(135 \pm$ $20, \mathrm{n}=9)$ wide. Testes $6-10(8 \pm 1, \mathrm{n}=10)$ in number, 29-58 (39 $\pm 6, n=32)$ in diameter; $1-2(2 \pm 0.4, n=10)$ preporally, $1-2(2 \pm$ $0.5, \mathrm{n}=10)$ postporally, 4-6 $(5 \pm 1, \mathrm{n}=10)$ antiporally. Cirrus sac near midproglottis, 58-83 (71 $\pm 7, \mathrm{n}=9)$ long by 58-77 (66 $\pm 6, \mathrm{n}$ $=9$ ) wide, containing spined eversible cirrus. Genital atrium indistinct. Genital pore $10-37 \%(27 \pm 6, n=18)$ of total length from anterior end, irregularly alternating. Vagina anterior to cirrus sac; vaginal sphincter not observed. Ovary near posterior end of proglottis, $\forall$-shaped in frontal view, $X$-shaped in cross section; 57-130 $(78 \pm 19, \mathrm{n}=25)$ wide at isthmus. Ovarian arms unequal in length but not reaching posterior margin of cirrus sac; aporal arm 141-224 $(175 \pm 31, n=7)$ long; poral arm 128-227 $(163 \pm 36, n=7)$ long. Uterus indistinct in mature proglottis. Vitelline follicles extending from level of ovarian isthmus to near anterior end of proglottis; follicles roughly spherical, 9-35 (16 \pm $5, \mathrm{n}=22$ ) in diameter.

\section{Taxonomic summary}

Host: Urolophus tumbesensis Chirichigno and McEachran (Rajiformes: Urolophidae).

Site of infection: Anteriormost chamber of spiral valve.

Locality: Puerto Hualtaco, Provincia de El Oro, Ecuador $\left(3^{\circ} 16^{\prime} \mathrm{S}\right.$ : $\left.80^{\circ} 19^{\prime} \mathrm{W}\right)$.

Holotype: MEPN no. 3030.

Paratypes: MNHG no. 22099; HWML no. 39178.

Etymology: The specific epithet refers to the tiny size, small bothridial hooks, and small number of testes per proglottis that characterize this species.

\section{Remarks}

Acanthobothrium minusculus resembles Acanthobothrium brevissime Linton, 1908 in Dasyatis sabina (LeSueur), Dasyatis sayi (LeSueur), Dasyatis americana Hildebrand and Schroeder, and Raja eglanteria Bosc from the Gulf of Mexico and the Chesapeake Bay, Virginia, USA; Acanthobothrium vargasi Marques, Brooks and Monks, 1995 in D. longus Garman from the Pacific coast of Costa Rica; Acanthobothrium campbelli Marques, Brooks and Monks, 1995 in Urotrygon chilensis (Günther) from the Pacific coast of Costa Rica; Acanthobothrium urotrygoni Brooks and Mayes, 1980 in Urotrygon venezuelae Schultz from the Caribbean coast of Colombia; Acanthobothrium quadripartitum Williams, 1968 in Raja naevus Müller \& Henle from North Sea and English Channel; and Acanthobothrium tripartitum Williams, 1969 in Raja microcellata Montagu from the English Channel by being very small worms, with strobilae not longer than $5 \mathrm{~mm}$ and having fewer than 30 proglottides, and with spinose peduncles, short bothridial hooks, and an average of fewer than 30 testes per proglottis. The new species is distinct from the other 6 by having fewer testes, $6-10$, per proglottis: A. vargasi has $22-29, A$. brevissime has $19-40$, A. campbelli has 1523 , A. urotrygoni has $24-33, A$. quadripartitum has 18 , and A. tripartitum has $13-16$. In the new species, the genital pore averages $27 \%$ of proglottis length from the anterior end rather than $44-50 \%$ for $A$. brevissime, A. vargasi, and A. campbelli, $38 \%$ for A. urotrygoni, and approximately $50 \%$ for A. quadripartitum and A. tripartitum. Acanthobothrium minusculus further differs from $A$. urotrygoni by having relatively shorter middle bothridial loculi, with a ratio of bothridial locular lengths of 1:0.27:0.30 rather than approximately 1:0.22:0.36 (USNPC no. 75163,2 paratypes). Further, A. minusculus can be distinguished from $A$. brevissime and $A$. vargasi by having shorter bothridia, from 176 to $224 \mu \mathrm{m}$ long rather than $260-360 \mu \mathrm{m}$ long for A. brevissime and 293-362 $\mu \mathrm{m}$ long for $A$. vargasi, shorter bothridial hooks, $80-100$ $\mu \mathrm{m}$ long rather than 96-151 $\mu \mathrm{m}$ long and 123-145 $\mu \mathrm{m}$ long, respectively, and shorter terminal proglottides, up to $529 \mu \mathrm{m}$ long rather than $1,000 \mu \mathrm{m}$ long and $825 \mu \mathrm{m}$ long, respectively. Acanthobothrium minusculus differs from $A$. campbelli by having shorter bothridial hooks, avaraging $86 \mu \mathrm{m}$ long (lateral and medial) rather than $108 \mu \mathrm{m}$ (lateral) and $111 \mu \mathrm{m}$ (medial) long, and slightly shorter bothridia, up to $203 \mu \mathrm{m}$ long vs. up to $264 \mu \mathrm{m}$ long. The new species is shorter, $1.3 \mathrm{~mm}$ long vs. $2.4 \mathrm{~mm}$ long, and has larger bothridia, $224 \mu \mathrm{m}$ vs. $196 \mu \mathrm{m}$ long, and $76-107 \mu \mathrm{m}$ vs. $60-61 \mu \mathrm{m}$ wide, than $A$. urotrygoni. The new spe- 

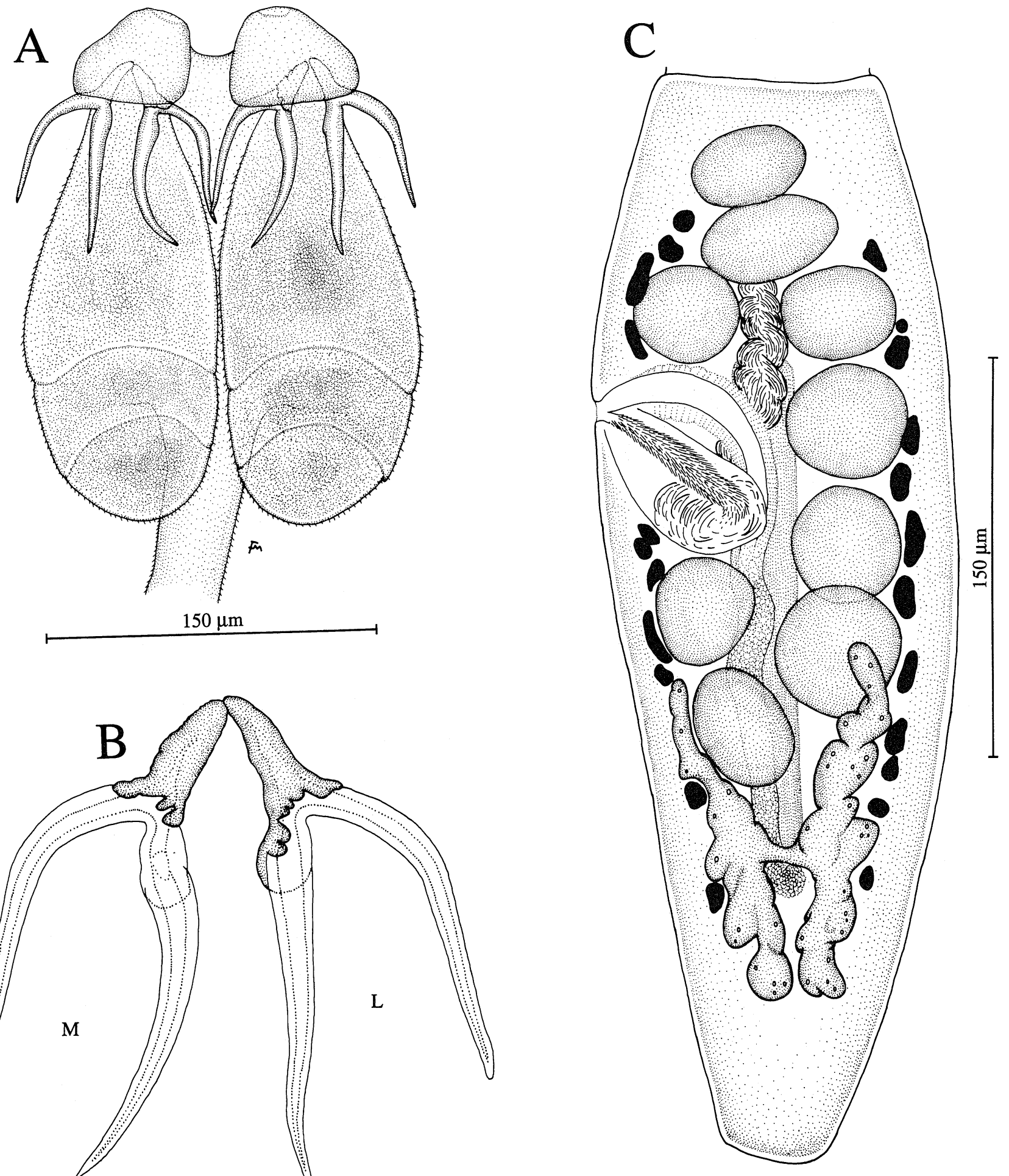

$50 \mu \mathrm{m}$

Figure 2. Acanthobothrium minusculus n. sp. A. Scolex. B. Medial and lateral hooks. C. Mature proglottis. M = medial hook; L = lateral hook. 
cies can be distinguished from $A$. quadripartitum by the general shape of the bothridial hooks; in A. quadripartitum the handle is vertically aligned with the inner prong, whereas in A. minusculus the handle is not aligned with either prong. Finally, A. minusculus differs from $A$. tripartitum by possessing 6-10 testes per proglottis rather than 13-16, and an average of 7 rather than 3 proglottides.

Acanthobothrium minusculus was the only species of Acanthobothrium encountered in this study for which it was possible to determine a specific localization in the intestine; specimens were found only in the anteriormost chamber of the spiral valve of all 5 specimens of $U$. tumbesensis examined.

\section{Acanthobothrium monksi n. sp.} (Fig. 3A-C)

Description (Based on 10 specimens): Strobila acraspedote, apolytic, 3.4-7.6 (5.4 $\pm 1.3, \mathrm{n}=8) \mathrm{mm}$ long; composed 24-48 $(33 \pm 8, \mathrm{n}=$ 9) of proglottides. Scolex 307-390 (356 $\pm 28, n=5)$ wide, composed of 4 triloculate bothridia free at posterior end with velum between adjacent bothridia; each bothridium with apical sucker and pad, armed with pair of bifid hooks. Bothridia 368-445 (401 $\pm 28, n=9)$ long by 166-189 (179 $\pm 8, n=6)$ wide; anterior loculi 224-262 $(244 \pm 13, \mathrm{n}$ = 9) long, middle loculi 64-96 $(79 \pm 10, n=9)$ long, posterior loculi 58-96 (79 $\pm 11, \mathrm{n}=9)$ long. Ratio of locular lengths 1:0.33:0.33. Muscular pads 131-144 (136 $\pm 5, \mathrm{n}=5)$ wide, bearing apical sucker 48-64 $(60 \pm 5, \mathrm{n}=8)$ in diameter. Hook formula for lateral hooks (n $=16)$ :

$$
\frac{51 \pm 5(42-58) \quad 109 \pm 4(102-115) \quad 93 \pm 5(83-106)}{151 \pm 7(141-160)}
$$

Hook formula for medial hooks $(\mathrm{n}=16)$ :

$$
\frac{50 \pm 5(44-60) \quad 106 \pm 6(98-113) \quad 91 \pm 4(85-98)}{149 \pm 8(132-161)}
$$

Ratio of bothridial length to total hook length 1:0.38 for lateral and medial hooks. Cephalic peduncle and scolex with spines. Peduncle 192 $384(290 \pm 65, \mathrm{n}=9) \mathrm{mm}$ long, 112-256 (199 $\pm 43, \mathrm{n}=9)$ wide at insertion to scolex. Immature proglottides wider than long. Mature terminal proglottides $282-570(475 \pm 86, \mathrm{n}=7)$ long by $218-374(297$ $\pm 48, \mathrm{n}=7)$ wide. Testes $26-42(36 \pm 4, \mathrm{n}=21)$ in diameter, $14-26$ $(21 \pm 4, \mathrm{n}=11)$ in number; $4-7(5 \pm 1, \mathrm{n}=11)$ preporally, 2-6 (4 $\pm 1, \mathrm{n}=11)$ postporally, $8-15(11 \pm 2, \mathrm{n}=11)$ antiporally. Cirrus sac near midproglottis, $102-214(156 \pm 33, \mathrm{n}=8)$ long, not reaching midline of proglottis, $128-163(146 \pm 14, \mathrm{n}=8)$ wide, containing spined eversible cirrus. Genital atrium prominent. Genital pore $34-47 \%$ ( $37 \pm 4, n=7)$ of total length from anterior end, irregularly alternating. Vagina anterior to cirrus sac; vaginal sphincter present. Ovary near posterior end of proglottis, $\mathrm{V}$-shaped in frontal view, $\mathrm{X}$-shaped in cross section; $88-183(135 \pm 24, \mathrm{n}=20)$ wide at isthmus. Ovarian arms unequal in length; aporal arm 102-253 (173 $\pm 37, \mathrm{n}=9)$ long, extending anteriorly to posterior margin of cirrus sac; poral arm 106-189 (157 $\pm 26, n=9)$ long, not reaching posterior margin of cirrus sac. Uterus indistinct in mature proglottis. Vitelline follicles extending from level of ovarian isthmus to near anterior end of proglottis; follicles roughly spherical, $13-32(21 \pm 6, n=10)$ in diameter.

\section{Taxonomic summary}

Host: Aetobatis narinari (Euphrasen) (Rajiformes: Myliobatidae).

Site of infection: Spiral valve.

Locality: Puerto Jelí, Provincia de El Oro, Ecuador $\left(3^{\circ} 16^{\prime} \mathrm{S}\right.$ $\left.80^{\circ} 19^{\prime} \mathrm{W}\right)$.

Holotype: MEPN no. 3031.

Paratypes: MNHG no. 22100; HWML no. 39179.

Etymology: The species is named for Mr. Scott Monks.

\section{Remarks}

Acanthobothrium monksi is closely resembles Acanthobothrium tasajerasi Brooks, 1977 in Himantura schmardae (Werner) from the Caribbean coast of Colombia, in having a large globose cirrus sac, large genital atrium, a ratio of bothridial loculi length of approximately 1: $0.33: 0.33$, and an average of $20-25$ testes per proglottis. However, the new species differs from $A$. tasajerasi by having an average of $21 \mathrm{vs.}$
35 testes per proglottis, and $24-48$ vs.11-18 proglottides per strobila. Additionally, A. monksi has smaller bothridial hooks (handle, 42-60 $\mu \mathrm{m}$; inner prong, 98-115 $\mu \mathrm{m}$; outer prong, 83-106 $\mu \mathrm{m}$; and total length, $132-161 \mu \mathrm{m}$ ) than $A$. tasajerasi (handle, 52-64 $\mu \mathrm{m}$; inner prong, $110-$ $130 \mu \mathrm{m}$; outer prong, 90-114 $\mu \mathrm{m}$; and total length, 152-178 $\mu \mathrm{m}$ ).

Other species of Acanthobothrium that are similar to A. monksi in scolex morphology and relative size of the cirrus sac include: Acanthobothrium colombianum Brooks and Mayes, 1980 in A. narinari (Euphrasen) from the Caribbean coast of Colombia; Acanthobothrium himanturi Brooks, 1977 in $H$. schmardae (Werner) also from the Caribbean coast of Colombia; Acanthobothrium lineatum Campbell, 1969 in D. americana Hilderbrand \& Schroeder from Chesapeak Bay, Virginia; and Acanthobothrium nicoyaense Brooks and McCorquodale, 1995 in A. narinari from the Pacific coast of Costa Rica. Acanthobothrium monksi can be distinguished from these species by possessing a prominent genital atrium that is lacking in the species above. Acanthobothrium monksi further resembles $A$. colombianum by having $31-48$ proglottides per strobila but differs by having an average of 36 rather than 46 testes per proglottis, and by having bothridial hooks with longer inner and outer prongs, averaging $185 \mu \mathrm{m}$ rather than $149 \mu \mathrm{m}$ in total length. Acanthobothrium monksi differs from A. himanturi by having shorter terminal proglottides $(277-561 \mu \mathrm{m}$ long vs. $780-1,260 \mu \mathrm{m})$, fewer testes per proglottis (14-26 vs. 38-40), and more proglottides per strobila (24-48 vs. 17-26). The new species differs from $A$. lineatum by having shorter bothridial hooks (132-161 $\mu \mathrm{m}$ long vs. 118-216 $\mu \mathrm{m})$, shorter terminal proglottides $(277-561 \mu \mathrm{m}$ vs. $700-1,500 \mu \mathrm{m})$, fewer testes per proglottis (14-26 vs. 28-45), and more proglottides per strobila (24-48 vs. 6-19). Finally, A. monksi can be distinguished from $A$. nicoyaense by having more proglottides per strobila (24-48 vs. $13-19)$ and longer terminal proglottides (277-561 $\mu \mathrm{m}$ long vs. $710-$ $1,261 \mu \mathrm{m}$ long).

\section{Acanthobothrium obuncus n. sp.} (Fig. 4A-C)

Description (based on 3 specimens): Strobila acraspedote, apolytic, up to $75.6 \mathrm{~mm}$ long; composed of up to 258 proglottides. Scolex up to 439 wide, composed of 4 triloculate sessile bothridia end with velum between adjacent bothridia; each bothridium with apical sucker and pad, armed with pair of bifid hooks. Bothridia 368-426 (399 $\pm 22 ; \mathrm{n}=6)$ long by $134-147(140 \pm 5, \mathrm{n}=5)$ wide; anterior loculi $234-256(245$ $\pm 8, \mathrm{n}=7)$ long, middle loculi 64-90 (78 $\pm 10, \mathrm{n}=7)$ long, posterior loculi 70-80 (76 $\pm 4, n=7)$ long. Ratio of locular lengths to total bothridial length 1:0.33:0.31. Muscular pad 141-170 $(158 \pm 9, n=4)$ wide, bearing apical sucker $33-48(39 \pm 5, \mathrm{n}=5)$ in diameter. Hook formula for lateral hooks $(n=2)$ :

$$
\frac{66 \quad 60-64 \quad 63-64}{126-130}
$$

Hook formula for medial hooks $(n=2)$ :

$$
\frac{62-66 \quad 56-58 \quad 56-58}{115-120}
$$

Ratio of bothridial length to total hook length 1:0.32 for lateral hooks and 1:0.30 for medial hooks. Cephalic peduncle and scolex without spines. Peduncle $26.7-27.8 \mathrm{~mm}$ long, 406-419 wide at insertion to scolex. Immature proglottides wider than long 174-374 (263 $\pm 48, \mathrm{n}=$ 28 ) long by $561-1,090(762 \pm 177, \mathrm{n}=28)$ wide; mature proglottides 426-683 $(540 \pm 82, n=14)$ long by $709-987(800 \pm 68, n=14)$ wide; terminal proglottides 709-774 $(750 \pm 24, \mathrm{n}=4)$ long by $645-$ $677(658 \pm 13, \mathrm{n}=4)$ wide. Testes $70-77(73 \pm 2, \mathrm{n}=11)$ in number, 45-90 $(67 \pm 10, \mathrm{n}=41)$ in diameter; $17-29(21 \pm 4, \mathrm{n}=10)$ preporally, $10-16(13 \pm 2, \mathrm{n}=10)$ postporally, $36-43(39 \pm 2, \mathrm{n}=10)$ antiporally. Cirrus sac near midproglottis, $258-322(293 \pm 22, n=14)$ long, not reaching midline of proglottis, by 116-271 $(163 \pm 43, n=$ 14) wide, containing spined eversible cirrus. Genital atrium indistinct. Genital pore $47-56 \%(51 \pm 3, n=14)$ of the total length from anterior end, irregularly alternating. Vagina anterior to cirrus sac; vaginal sphincter absent. Ovary near posterior end of proglottis, U-shaped in frontal view, $\mathrm{X}$-shaped in cross section; $645-1,245(763 \pm 216, \mathrm{n}=16)$ wide at isthmus. Ovarian arms unequal in length; aporal arm 258-484 (415 $\pm 75, n=6$ ) long, extending anteriorly to middle of cirrus sac; poral arm $161-258(221 \pm 35, n=6)$ long, extending anteriorly to posterior 

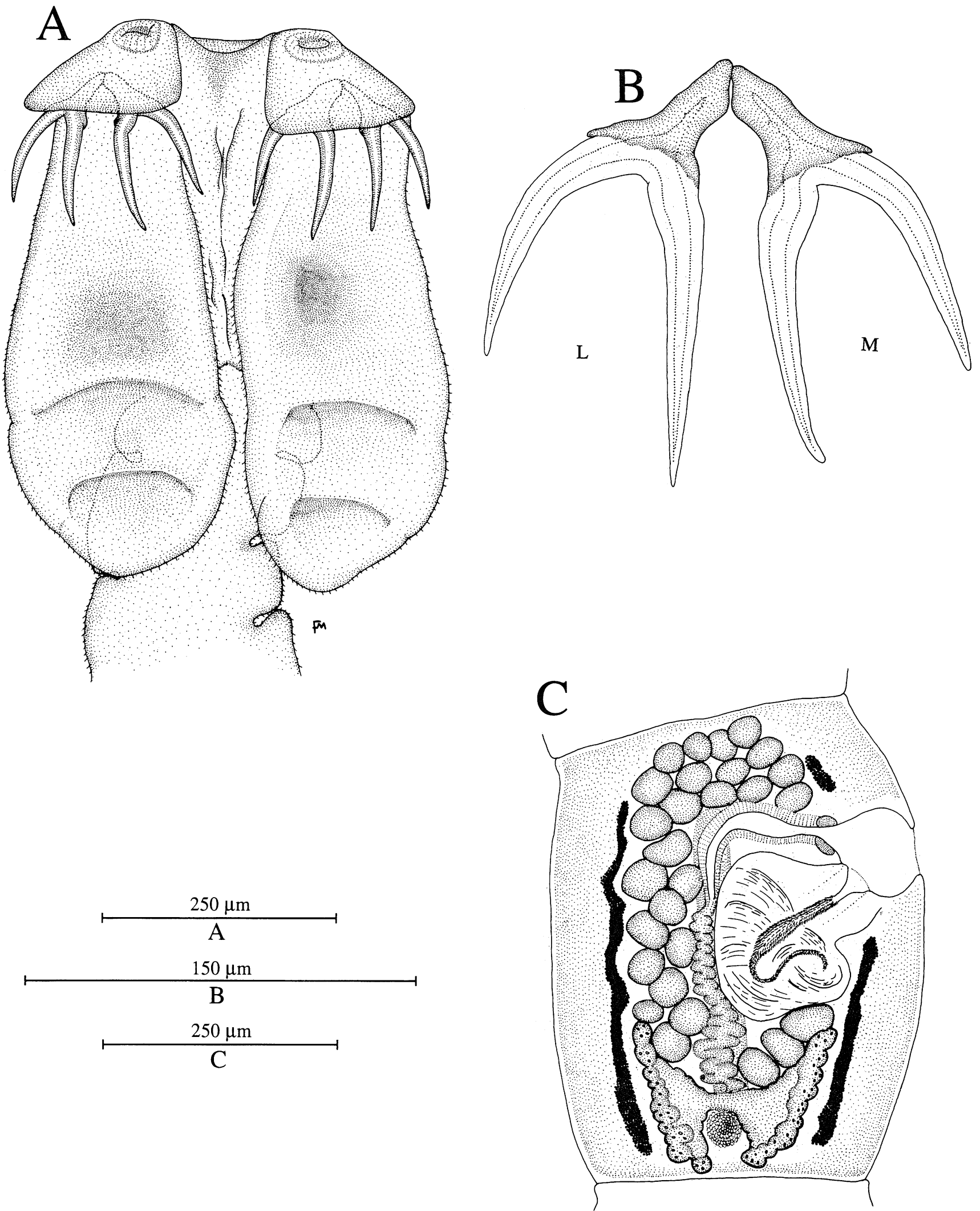

Figure 3. Acanthobothrium monksi $\mathrm{n}$. sp. A. Scolex. B. Medial and lateral hooks. C. Mature proglottis. M $=$ medial hook; L $=$ lateral hook. 

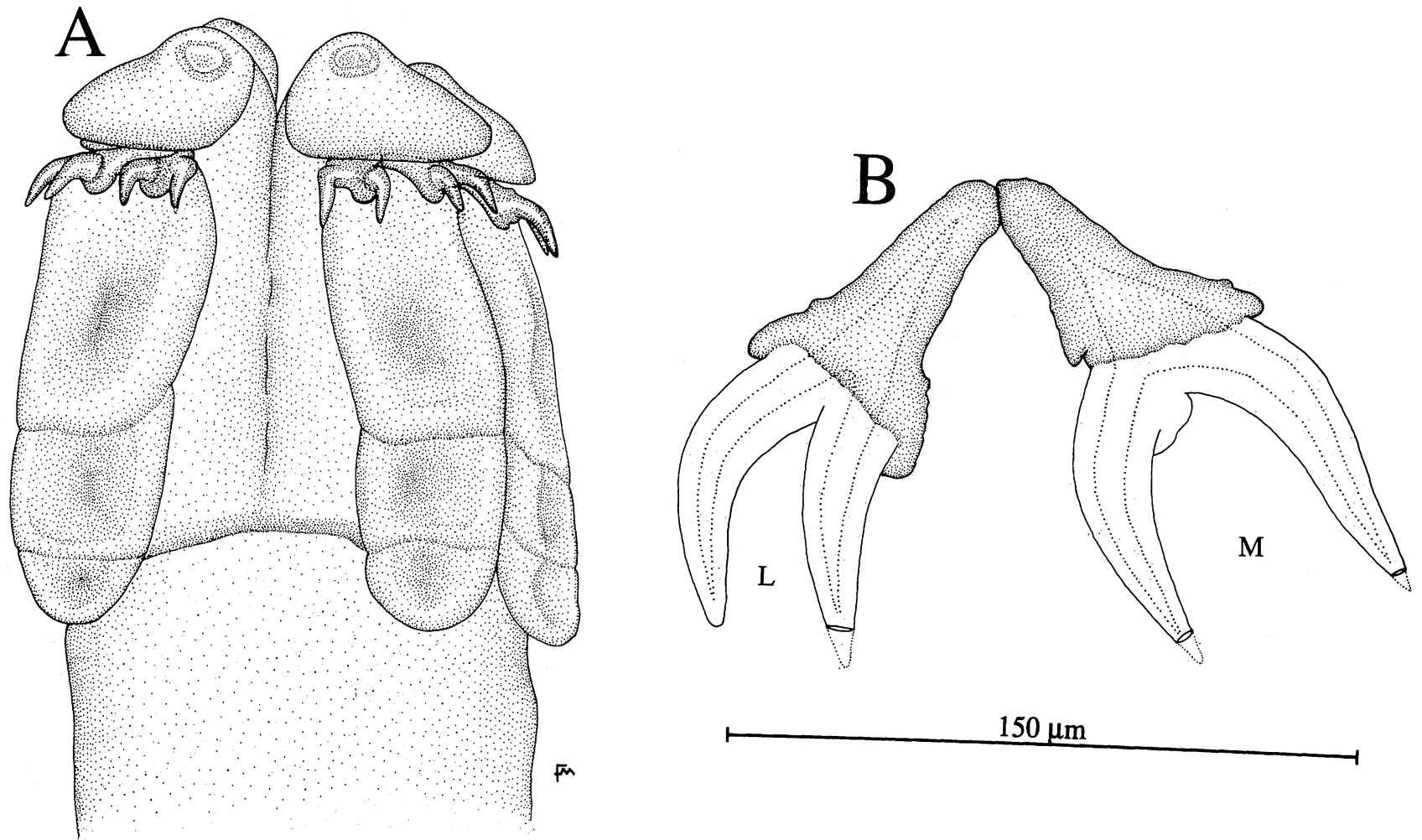

$500 \mu \mathrm{m}$

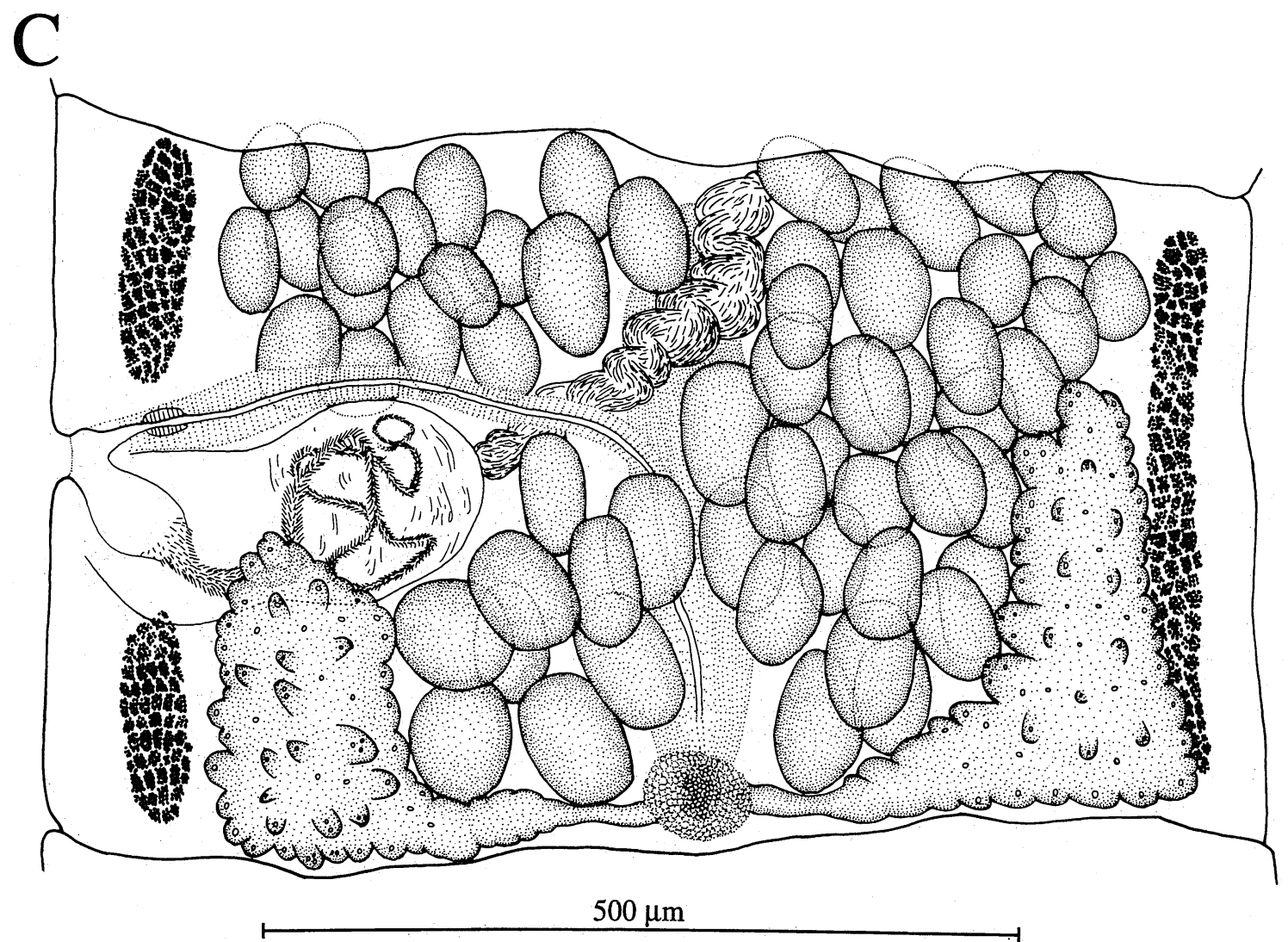

Figure 4. Acanthobothrium obuncus n. sp. A. Scolex. B. Medial and lateral hooks. C. Mature proglottis. M $=$ medial hook; L $=$ lateral hook. 
margin of cirrus sac. Uterus indistinct in mature proglottis. Vitelline follicles extending from level of ovarian isthmus to near anterior end of proglottis; follicles roughly spherical, $13-23(17 \pm 3, n=10)$ in diameter.

\section{Taxonomic summary}

Host: Dasyatis longus Garman (Rajiformes: Dasybatididae).

Site of infection: Spiral valve.

Locality: Puerto Hualtaco, Provincia de El Oro, Ecuador $\left(3^{\circ} 16^{\prime} \mathrm{S}\right.$ : $\left.80^{\circ} 19^{\prime} \mathrm{W}\right)$.

Holotype: MEPN no. 3032.

Paratypes: MNHG no. 22101; HWML no. 39180

Etymology: From the Latin "obuncus" which means "hook bent in" in reference to the hook shape of this species.

\section{Remarks}

Acanthobothrium obuncus resembles those species of Acanthoboth rium with aspinose scoleces, muscular bothridia at least partially fused to the scolex at their posterior ends, bothridial hooks usually less than $1 / 3$ the length of the bothridial, flat or low $\mathrm{H}$ - to $\mathrm{V}$-shaped ovaries with symmetrical to asymmetrical arms extending anteriorly to, or nearly to, the cirrus sac, and vitellaria arranged in fields rather than a single or double row of follicles (see also Monks et al., 1996): A. americanum Campbell, 1969 in D. americana Hildebrand \& Schroeder from Virginia; Acanthobothrium chengi Cornford, 1974 in Dasyatis lata Jordan \& Everman from Hawaii; Acanthobothrium chilensis Rêgo, Vicente, and Ibáñez, 1968 in Sarda chilensis (Cuvier) from Peru; A. crassicole Wedl, 1885 in Dasyatis pastinaca (L.), Dasyatis kuhlii Müller and Henle, Raja radiata Donovan (= Raja clavata), and Torpedo marmorata Risso throughout the eastern North Atlantic and Mediterranean Sea (see Goldstein, 1967); Acanthobothrium dasybati Yamaguti, 1934 in Dasyatis akajei Müller \& Henle, Urolophus fuscus Garman, and Raja kenojei Müller \& Henle from Japan; Acanthobothrium dighaensis Srivastav and Capoor, 1980 in Trygon marginatus (Blyth) from India; Acanthobothrium icelandicum Nanger, 1972 in Raja batis L. from Iceland; Acanthobothrium latum Yamaguti, 1952 in D. akajei from Japan; Acanthobothrium micrantha Yamaguti, 1952 in D. akajei from Japan; Acanthobothrium microcephalum Alexander, 1953 in Myliobatis californicus (Gill) from California; Acanthobothrium rubrum Bilqees, 1980 in Myr myllo manazo (BLK) from Pakistan; Acanthobothrium tortum (Linton, 1916) in A. narinari (Euphrasen) from Florida; and Acanthobothrium wedli Robinson, 1959 in Raja nasuta Müller \& Henle from New Zealand. By exhibiting asymmetrical ovarian arms with the aporal arm extending anteriorly to the vaginal level and an average of 73 testes per proglottis, the new species resembles $A$. americanum (averaging 72 testes per proglottis), A. chilensis (80-100 testes per proglottis), A. rubrum (60-87 testes per proglottis), and $A$. wedli ( $80-100$ testes per proglottis). All but 1 of the remaining species, some of which also exhibit asymmetrical ovarian arms, can be readily distinguished from $A$. obuncus by averaging more than 100 testes per proglottis. Acanthobothrium dasybatis can be readily distinguished from A. obuncus by having 40-70 testes per proglottis. The new species differs from A. americanum by having shorter bothridial hooks (averaging $120 \mu \mathrm{m}$ [medial] and 131 $\mu \mathrm{m}$ [lateral] vs. $151 \mu \mathrm{m}$ long) and fewer proglottides per strobila (258 vs. 507). Acanthbothrium obuncus differs from A. chilensis by having shorter bothridia (362-419 $\mu \mathrm{m}$ vs. $706-840 \mu \mathrm{m}$ long; CHIOC 30308a, $\mathrm{b}$ - paratypes) and possessing slightly fewer testes per proglottis (7077 vs. 80-100). The new species differs from $A$. rubrum by having shorter hooks (130-133 $\mu \mathrm{m}$ [lateral] and 118-123 $\mu \mathrm{m}$ [medial] vs. 470$490 \mu \mathrm{m}$ ) and fewer proglottides per strobila (up to 258 vs. 596). Finally, A. obuncus differs from A. wedli by having larger bothridial hooks (averaging $120 \mu \mathrm{m}$ [medial] and $131 \mu \mathrm{m}$ [lateral] vs. 90-105 $\mu \mathrm{m}$ long) and slightly fewer testes per proglottis (70-77 vs. $80-100)$.

\section{Acanthobothrium campbelli Marques, Brooks, and Monks, 1995}

\section{Taxonomic summary} host.

Host: Dasyatis longus Garman (Rajiformes: Dasybatididae), new Site of infection: Spiral valve.
Locality: Puerto Hualtaco, Provincia de El Oro, Ecuador $\left(3^{\circ} 16^{\prime} \mathrm{S}\right.$ : $\left.80^{\circ} 19^{\prime} \mathrm{W}\right)$, new locality.

Voucher specimens: MEPN no. 3033.

\section{Acanthobothrium costarricense}

\section{Taxonomic summary}

\section{Marques, Brooks, and Monks, 1995}

Host: Dasyatis longus Garman (Rajiformes: Dasybatididae).

Site of infection: Spiral valve.

Locality: Puerto Hualtaco, Provincia de El Oro, Ecuador $\left(3^{\circ} 16^{\prime} \mathrm{S}\right.$ : $\left.80^{\circ} 19^{\prime} \mathrm{W}\right)$, new locality.

Voucher specimens: MEPN no. 3034.

Both of these species were previously known only from their type locality, near Punta Morales in the Gulf of Nicoya, Costa Rica; this report thus constitutes new geographic distribution records for both species. Acanthobothrium campbelli was described originally in U. chilensis, so $D$. longus represents a new host record.

\section{DISCUSSION}

This study raises to 27 the number of species of Acanthobothrium reported from the eastern Pacific: 12 from California, 1 from Mexico, 4 from Costa Rica, 4 from Ecuador, 2 from Costa Rica and Ecuador, 1 from Peru, and 3 from Chile (Table I). Acanthobothrium coronatum (Rudolphi, 1819) and A. dujardini Benede, 1949, which have been reported from California, are European endemics, and thus the reports from California are undoubtedly misidentifications (see Goldstein, 1967). At present, only $A$. campbelli and $A$. costarricense are known from more than a single locality. We assume that additional inventories will add new species to this list and extend the geographical ranges of previously known species. Despite the undoubtedly incomplete nature of our database, it is clear that the species-rich nature of Acanthobothrium makes the group an excellent model system for a variety of evolutionary studies. Although we do not have a formal phylogenetic hypothesis for the entire genus at present, some components of relationships have begun to emerge.

First, we have now identified 6 probable pairs of sister species of Acanthobothrium occurring on each side of the Isthmus of Panama (geminate species sensu Jordan, 1908): A. nicoyaense and $A$. colombianum in $A$. narinari; $A$. vargasi in $D$. longus and $A$. brevissime in $D$. sayi, $D$. sabina, $D$. americana, and Raja eglanteria; A. campbelli in $U$. chilensis and A. urotrygoni in $U$. venezuelae; $A$. monksi in $D$. longus and A. tasajerasi in $H$. schmardae; $A$. atahualpai in $G$. afuerae and $A$. fogeli in $G$. micrura; and $A$. obuncum in D. longus and $A$. americanum in $D$. americana. It is also possible that either $A$. costarricense or $A$. cimari, both in $D$. longus, is the sister species of $A$. himanturi in $H$. schmardae or A. lineatum in D. americana. Marques et al. (1996) described Acanthobothroides pacificus and Rhinebothrium geminum in Himantura pacifica, listing synapomorphic traits indicating that they are the sister species of Acanthobothroides thorsoni and Rhinebothrium magniphallum in Himantura schmardae and Dasyatis guttata (Bloch and Schneider) from the Caribbean coasts of Colombia and Venezuela. As discussed by Marques et al. (1996), these apparent connections between the eastern Pacific and Caribbean helminth fauna of elasmobranchs probably date from the most recent formation of the Panamian Isthmus in the Pliocene.

A second major component of the eastern Pacific Acanthobothrium fauna is a morphologically similar species that exhibit 
, AND M. A. MAYES. 1978. Acanthobothrium electricolum sp n. and A. lintoni Goldstein, Henson and Schlicht, 1969 (Cestoda: Tetraphyllidea) from Narcine brasiliensis (Olfers) in Colombia. Journal of Parasitology 64: 617-619.

, AND D. A. McLennan. 1993. Parascript: Parasites and the language of evolution. Smithsonian Institution Press, Washington, D.C., $429 \mathrm{p}$

DIETZ, R. S., AND J. C. Holden. 1970. Reconstruction of Pangaea Breakup and dispersion of continents, Permian to present. Journal of Geophysical Research 72: 4949-4956.

GoldsteIN, R. J. 1967. Analysis of the genus Acanthobothrium van Beneden, 1849 (Cestoda: Tetraphyllidea). Journal of Parasitology 53: $455-483$.

JoRDAN, D. S. 1908. The law of geminate species. American Naturalist 42: $73-80$.

LOVEJOY, N. R. 1996. Systematics of Myliobatoid elasmobranchs with emphasis on the phylogeny and biogeography of the neotropical freshwater stingrays (Potamotrygonidae). Zoological Journal of the Linnean Society (in press).

Marques, F., D. R. BRooks, AND S. Monks. 1995. Five new species of Acanthobothrium van Beneden, 1859 (Eucestoda: Tetraphyllidea: Onchobothriidae) in stingrays from the Gulf of Nicoya, Costa Rica. Journal of Parasitology 81: 942-951.

- , - AND H. M. UREÑA. 1996. Two new species of tetraphyllidean cestodes in Himantura pacifica (Chondrichthyes: Myliobatiformes: Dasyatididae) from northwest coast of Costa Rica. Journal of Parasitology 82: 302-306.

Monks, S., D. R. Brooks, ANd G. Pérez Ponce de León. 1996. A new species of Acanthobothrium (Eucestoda: Tetraphyllidea: Onchobothriidae) in Dasyatis longus (Chondrichthyes: Myliobatiformes: Dasyatididae) from Chamela Bay, Jalisco, Mexico. Journal of Parasitology 82: 484-488.

WhITE, B. N. 1982. The isthmian link, antitropicality and American biogeography: Distributional history of the Atherinopsinae (Pisces: Atherinidae). Systematic Zoology 35: 176-194. 